\title{
Phosphorus Use Efficiency in Canola Genotypes
}

\author{
Kürşat Korkmaz , Çağatay Altıntaş
}

Department of Soil Science and Plant Nutrition, Faculty of Agriculture, Ordu University, 52200 Ordu, Turkey A R T I C L E I N F O

\section{Article history:}

Received 08 April 2016

Accepted 10 July 2016

Available online, ISSN: 2148-127X

Keywords:

Brassica napus L.

Phosphorus uptake

Efficiency Index Physical

$P$ fertilization

$\mathrm{P}$ efficiency

${ }^{*}$ Corresponding Author:

E-mail: korkmaz60@gmail.com

\section{A B S T R A C T}

Phosphorus (P) deficiency is a widespread macronutrient deficiency and is one of the major constraints limiting canola production. Efficient P fertilizer method's is important for economic production of canola and sustaining of environmental quality. The aim of this research is to investigate P use efficiency (PUE) of canola genotypes at an early growth stage. The experiment was set up as a completely randomized design in a factorial scheme. The factors were ten canola genotypes (Excalibur, Nelson, Vectra, Orkan, Triangel, TKK08-5, Oase, Elvis, Es Hydromel and Licord) and three P rates (0, 50 and $100 \mathrm{mg} \mathrm{kg}^{-1}$ ). The plant parameters, dry weight of shoot and root varies significantly with $\mathrm{P}$ levels in all applications. In general, $\mathrm{P}$ concentrations and dry weight of the genotypes are linearly raised by $\mathrm{P}$ treatments. The genotype Elvis produced significantly higher shoot dry matter $9.24 \mathrm{~g} \mathrm{pot}^{-1}$ at $100 \mathrm{mg} \mathrm{kg}^{-1} \mathrm{P}$ rate compared to the other applications. However, without $\mathrm{P}$, dry matter (DM) of genotypes varied between 1.67 to $6.96 \mathrm{~g} \mathrm{pot}^{-1}$. Cultivars classified as efficient responsive are: Elvis, inefficient responsive: Nelson, Orkan, Oase, Licord, and efficient nonresponsive: Excalibur, Vectra, Triangel, TKK08-5, Es Hydromel. Plant dry matter can be used for identification of the genotypes which could be adapted to low or high soil $\mathrm{P}$ availability conditions at an early growth stage. Nutrient use efficiency and genotypic differences in plants should be considered in order to create an accurate and a balanced fertilizer program as well as improving crop yield in agricultural production system.

\section{Introduction}

Canola (Brassica napus L.) also known as rape is a perfect rotation crop for cereals (Brennan et al 2000). Besides, in recent years, rising costs of fossil fuels and their adversely affects have greatly increased interest in growing biofuel crops, such as canola for production of biodiesel in the world. Canola yield and quality depend upon the environment, genotype, and their interactions. Low soil fertility, especially phosphorus (P) deficiency one of the major constraints limiting canola yield (Grant and Bailey 1993). However, right $P$ fertilization is critical in the very early phase of canola (Bolland 1997). However, excessive $\mathrm{P}$ fertilization in the soil raises the risk of water pollution, leading to the eutrophication (Sharpley et al 1994). Phosphorus mobility in soil is low compared to other nutrients (Mengel and Kirkby 1987). High $\mathrm{P}$ fixation capacity in soil by lime and Fe oxides is the limiting factor for $\mathrm{P}$ availability in soil (Bertland et al 2003). Many studies have been done to clarify the contribution of soluble $\mathrm{Ca}$-ions to precipitation (Saltali et al., 2007). The specific adsorption of $\mathrm{P}$ on variable minerals such as $\mathrm{Fe}$ and $\mathrm{Al}$ oxides and clay has been shown to be responsible for the low plant availability of both applied and native soil P (Korkmaz et al., 2009). Moreover, according to some predictions, $\mathrm{P}$ resources of world may run out by 2050 (Vance et al 2003). Increasing fertilizer prices and general awareness of the need for conservation of soil, water and energy and the control of ground water pollution further fueled the idea of modifying plants instead of soils for solving the problem of P deficiencies of soils (Erkovan et al., 2010). Soil type, genotypic variability and phosphorus rates are the factors affecting $\mathrm{P}$ uptake of plants in growth media. Especially, genotypic differences have been shown to be related with PUE (Korkmaz et al 2009). The variation in phosphorus uptake among plants will support decrease costs of phosphorus fertilization and increase fertility with more P-efficient plant. $\mathrm{P}$ efficient plants are able to produce high yield at relatively low soil $\mathrm{P}$ conditions (Rengel 1999). Plant species, even in genotypes within the same species, are known to show differences from the point of P use efficiency (Fohse et al 1991). Phosphorus efficiency of plants may stem from the ability to take up more $\mathrm{P}$ from the soil under low $\mathrm{P}$ condition or the ability to produce higher dry matter per unit of $\mathrm{P}$ in the plant tissue or from both of these properties (Blair 1993). The concept of plant $\mathrm{P}$ efficiency is still not sufficiently understood in practice greatly because of excessive $\mathrm{P}$ fertilization in plant production systems. Cultivars are divided into four groups based on $\mathrm{P}$ use efficiency: (i) efficient responsive, (ii) inefficient responsive, (iii) efficient non-responsive and (iv) inefficient nonresponsive (Gerloff 1977). Genotypic differences may be a crucial strategy for improved $\mathrm{P}$ acquisition during low $\mathrm{P}$ availability in soil (Watt and Evans 1999; Terrence et al 2001; Wissua 2002, Korkmaz et al 2009). Limited research has been done on the effects of $\mathrm{P}$ use efficiency 
(PUE) in relation to genetic variations for PUE of canola. Hence, this study is initiated to study the variations in PUE traits, and to do research the screening quality that can be used to identify early growth phase of canola genotypes to PUE.

\section{Materials and Methods}

A canola-greenhouse trial was carried out at Ordu Univ., Soil Science Department in 2011. Soil samples were taken from the 0-30-cm-depth in Ordu University's research area, air-dried, and placed in plastic pots at $3 \mathrm{~kg}$ per pot. The experiment was set up as a completely randomized design in a factorial scheme with three replication. The factors were ten canola genotypes (Excalibur, Nelson, Vectra, Orkan, Triangel, TKK08-5, Oase, Elvis, Es Hydromel and Licord) and three $\mathrm{P}$ rates $\left(0,50\right.$ and $\left.100 \mathrm{mg} \mathrm{kg}{ }^{-1}\right)$. Some characteristics of the canola genotypes and line were shown in Table 1.

Phosphorus was added as mono potassium phosphate $\left(\mathrm{KH}_{2} \mathrm{PO}_{4}\right)$ in nutrient solution at three $\mathrm{P}$ rates $(0,50$ and $100 \mathrm{mg} \mathrm{kg}^{-1}$ ). Eight seeds were planted in dark colored pots, and thinned to three after germination. A main application of $\mathrm{N}, \mathrm{K}$ and micronutrients were put in to the pots as liquid, and distilled water was added to bring them to approximate field capacity before seeding. The pots were ordered in a completely randomized design with four replications. The soils were previously analyzed for Olsen-P to determine low extractable $\mathrm{P}$ containing soil which were specifically selected to better observe $\mathrm{P}$ response of plants. Additionally, selected physical and chemical analysis of soil was also completed (Table 2). Phosphorus and other nutrients were put in to soils as liquid from the surface, and the soils were brought to roughly field capacity before seeding using distilled water.

At harvest, plant and root samples were gathered from each of the pots. The pots were filled with a diluted sodium bicarbonate solution as a dispersing material. The roots were washed and cleaned in the pot with distilled water. The dry weight of plants were determined for each pot. Plants were harvested 58 days after seeding by cutting at $1-\mathrm{cm}$ above the surface. They were washed with deionized water and dried at $65^{\circ} \mathrm{C}$.analysis. Plant samples were dry ashed at $550^{\circ} \mathrm{C}$ for over night and diluted using $0.3 \mathrm{~N} \mathrm{HCl}$ to bring nutrients into the solution, and the solution was filtered. Phosphorus contents of the samples were specified as for Murphy and Riley (1962). The other parameters were measured or calculated: shoot and root weight, $\mathrm{P}$ concentration, $\mathrm{P}$ uptake, $\mathrm{P}$ efficiency ratio and efficiency index (EI) in plants. The phosphorus efficiency ratio was estimated by dividing shoot dry matter in control with proper $\mathrm{P}\left(\mathrm{P}=100 \mathrm{mg} \mathrm{P} \mathrm{kg}^{-1}\right)$ (Ozturk et al 2005). P content and dry weight of the plant samples were used to determine the efficiency index parameter (EI) ( $\mathrm{g}^{2} /$ shoot $\mathrm{P}$ concentration) for categorization of plants (adapted from Siddiqi and Glass 1981). Data were statistically analyzed by ANOVA (MSTAT software).

\section{Results and Discussion}

\section{Dry Weight and P Efficiency of Plants}

Shoot dry weight ranged from 1.67 to $9.24 \mathrm{~g} \mathrm{pot}^{-1}$, and root dry weight varied from 0.11 to $0.86 \mathrm{~g} \mathrm{pot}^{-1}$ for the ten genotypes in the $\mathrm{P}$ applications levels (Table 3 and Table 4). The shoot/root ratio varied from 0.06 to 0.08 and did not show distinction between the genotypes or $\mathrm{P}$ rates (data not shown). Table 2 shows that shoot dry weight varies considerably among $\mathrm{P}$ applications. The genotype Elvis produced significantly higher shoot dry matter 9.24 $\mathrm{g} \mathrm{pot}^{-1}$ at $100 \mathrm{mg} \mathrm{kg}^{-1} \mathrm{P}$ rate compared to the other applications. Increasing P rate raised the growth of plant. In general, it indicates that all of the genotypes developed poor dry matter at low $\mathrm{P}$ levels. In this study, mean DM yield varied between 1.67 to $6.96 \mathrm{~g} \mathrm{pot}^{-1}$; the Licord Nelson, Oase and Orkan genotypes composed little DM without P application (Table 3), but TKK08-5, Excalibur, Es Hydromel, Vectra, Elvis, Triangel produced well without $\mathrm{P}$ application. Phosphorus fertilization helped dry matter of the genotypes reached to maximum at the rate of $100 \mathrm{mg} \mathrm{kg}^{-1} \mathrm{P}$ application. The shoot and root dry matters were found to be influenced by the genotypes and $\mathrm{P}$ rates $(\mathrm{P}<0.001)$. The interactions of $\mathrm{P}$ with genotype weren't significant $(\mathrm{P}=0.001)$ in the dry matter.

Phosphorus efficiency index and $\mathrm{P}$ efficiency ratio for $P$ response among the genotypes were shown in Table 5. Phosphorus efficiency ratio showed significant differences (53 to 94\%) among the canola genotypes. These values were used in classification to explain $\mathrm{P}$ utilization. The mean $\mathrm{P}$ efficiencies ratio was found to be $69.6 \%$. The genotypes were evaluated to be efficient when the $\mathrm{P}$ efficiency ratio were above average $(70 \%)$ in this study. According to $\mathrm{P}$ efficiency ratio Excalibur, Vectra, Triangel, TKK08-5 and Es Hydromel were classified as $\mathrm{P}$ efficient genotypes.

Table 1 Some characteristics of canola varieties and line

\begin{tabular}{l|lccc}
\hline Cultivar/Line & \multicolumn{1}{|c}{ Maintainer } & Country of Origin/years of relaese & Winter (w) or Spring(s) & Reclamation \\
\hline Excalibur & Monsanto Seed Company & USA & $\mathrm{s}$ & Hybrid \\
Nelson & Syngenta Seed Company & Sweeden/2005 & w & Hybrid \\
Vectra & Agromar Seed Company & Germany & w & Hybrid \\
Orkan & Agromar Seed Company & Germany/2007 & W & Selection \\
Triangel & KWS Turk Seed Company & Germany & s & Hybrid \\
TKK08-5 & unknown & Turkey & w & Hybrid \\
Oase & Çimsan Seed Company & Germany & w & Hybrid \\
Elvis & TAT seed company & Germany/2007 & w & Hybrid \\
Es Hydromel & TAT seed company & Germany/2005 & w & Hybrid \\
Licord & Çimsan seed company & Germany/2005 & & \\
\hline
\end{tabular}


Table 2 Some physical and chemical properties of soil

\begin{tabular}{l|c}
\hline $\mathrm{N}(\%)$ & 0.17 \\
$\mathrm{P}\left(\mathrm{mg} \mathrm{kg}^{-1}\right)$ & 3.52 \\
$\mathrm{~K}\left(\mathrm{mg} \mathrm{kg}^{-1}\right)$ & 190 \\
$\mathrm{Ca}\left(\mathrm{mg} \mathrm{kg}^{-1}\right)$ & 3985 \\
$\mathrm{Mg}\left(\mathrm{mg} \mathrm{kg}^{-1}\right)$ & 266 \\
$\mathrm{Fe}\left(\mathrm{m} \mathrm{kg}^{-1}\right)$ & 11 \\
$\mathrm{Zn}\left(\mathrm{mg} \mathrm{kg}^{-1}\right)$ & 1.7 \\
$\mathrm{Cu}\left(\mathrm{mg} \mathrm{kg}^{-1}\right)$ & 0.23 \\
$\mathrm{Mn}\left(\mathrm{mg} \mathrm{kg}^{-1}\right)$ & 32 \\
$\mathrm{pH}$ & 6.33 \\
Organic Matter $(\%)$ & 1.95 \\
Texture & $\mathrm{CL}$ \\
\hline
\end{tabular}

Table 3 Shoot dry matter yield of the ten canola genotypes $\left(\mathrm{g} \mathrm{pot}^{-1}\right)$

\begin{tabular}{l|cccc}
\hline P Rates $\left(\mathrm{mg} \mathrm{kg}^{-1}\right)$ & 0 & 50 & 100 & Mean \\
\hline Excalibur & 6.87 & 7.21 & 8.34 & 5.47 \\
Nelson & 3.63 & 5.20 & 6.48 & 6.52 \\
Vectra & 5.37 & 6.88 & 7.31 & 4.62 \\
Orkan & 3.46 & 5.13 & 5.27 & 7.37 \\
Triangel & 5.99 & 7.58 & 8.56 & 7.85 \\
TKK08-5 & 6.96 & 9.15 & 7.44 & 5.21 \\
Oase & 3.86 & 6.00 & 5.77 & 7.35 \\
Elvis & 4.91 & 7.89 & 9.24 & 6.67 \\
Es Hydromel & 5.71 & 6.98 & 7.32 & 2.33 \\
Licord & 1.67 & 2.38 & 2.96 & \\
& 4.84 & 6.44 & 6.87 & \\
F Test & & & & \\
Genotype & $* * *$ & & \\
Rate & $* * *$ & & \\
Genotypes x Rate & $\mathrm{NS}$ & &
\end{tabular}

Table 4 Root dry matter yield of the ten canola genotypes $\left(\mathrm{g} \mathrm{pot}^{-1}\right)$

\begin{tabular}{l|cccc}
\hline P Rates $\left(\mathrm{mg} \mathrm{kg}^{-1}\right)$ & 0 & 50 & 100 & Mean \\
\hline Excalibur & 0.49 & 0.59 & 0.63 & 0.75 \\
Nelson & 0.21 & 0.31 & 0.41 & 0.31 \\
Vectra & 0.36 & 0.53 & 0.61 & 0.50 \\
Orkan & 0.20 & 0.29 & 0.35 & 0.54 \\
Triangel & 0.41 & 0.55 & 0.67 & 0.68 \\
TKK08-5 & 0.50 & 0.86 & 0.69 & 0.36 \\
Oase & 0.24 & 0.45 & 0.38 & 0.53 \\
Elvis & 0.35 & 0.57 & 0.68 & 0.41 \\
Es Hydromel & 0.34 & 0.41 & 0.49 & 0.16 \\
Licord & 0.11 & 0.18 & 0.20 & \\
& 0.32 & 0.47 & 0.51 & \\
\hline F Test & & & & \\
Genotype & $* * *$ & & \\
Rate & $* * *$ & & \\
Genotypes x Rate & NS & & & \\
\hline *** statically 0.001 level significant, NS non significant. & &
\end{tabular}

Table 5 Efficiency Ratio and Efficiency Index of Canola Genotypes ${ }^{1}$

\begin{tabular}{l|ccccc}
\hline P Rates (mg kg-1) & 0 & 50 & 100 & Mean & P Efficiency Ratio \\
\hline Excalibur & 1.3 & 1.2 & 1.4 & 1.3 & 82 \\
Nelson & 0.8 & 0.9 & 1.1 & 0.9 & 56 \\
Vectra & 1.1 & 1.2 & 1.3 & 1.2 & 74 \\
Orkan & 0.8 & 0.9 & 0.9 & 0.9 & 66 \\
Triangel & 1.2 & 1.3 & 1.4 & 1.3 & 70 \\
TKK08-5 & 1.5 & 1.7 & 1.2 & 1.5 & 94 \\
Oase & 0.8 & 1.1 & 0.9 & 0.9 & 67 \\
Elvis & 1.1 & 1.5 & 1.7 & 1.4 & 53 \\
Es Hydromel & 1.3 & 1.2 & 1.2 & 1.2 & 78 \\
Licord & 0.3 & 0.4 & 0.5 & 0.4 & 56 \\
Mean & 1.0 & 1.1 & 1.2 & 1.1 & 69.6 \\
\hline
\end{tabular}


The efficiency index (EI) of the plants was calculated based on biomass production per unit of $\mathrm{P}$ in the plant tissue. About four-fold differences (from 0.4 to 1.5 ) were determined for the values in low $\mathrm{P}$ conditions among the genotypes (Figure 1). Based on the EI, the ten canola genotypes were put in to one of the four categories, efficient responsive, inefficient responsive, efficient nonresponsive, and inefficient nonresponsive (Figure 1).

Genotypic differences were observed among varieties of canola under conditions of $\mathrm{P}$ deficiency. The plants categorized as efficient-responsive were: Elvis, which produced above average dry matter yield and responded well to $\mathrm{P}$ application; inefficient-responsive: Nelson, Orkan, Oase, Licord, which produced less than average dry matter yield, but responded well to $\mathrm{P}$ application, and efficient-non-responsive Excalibur, Vectra, Triangel, TKK08-5, Es Hydromel which produced above than average, but responded to $\mathrm{P}$ application.
Phosphorus Concentration and Uptake of Genotypes

Shoot phosphorus concentration varied from 0.45 to $0.61 \%$, and root phosphorus concentration varied from 0.28 to $0.77 \%$ for the ten genotypes in the $\mathrm{P}$ applications levels (Figure2.)

The shoot and root $\mathrm{P}$ concentration were found to be influenced by the genotypes and $\mathrm{P}$ levels $(\mathrm{P}<0.001)$. The interactions of $\mathrm{P}$ levels with genotype weren't significant $(\mathrm{P}=0.001)$ in the $\mathrm{P}$ concentration. Phosphorus uptake of the canola genotypes varied between 1.19 to $2.00 \mathrm{mg} P$ pot $^{-1}$ without $\mathrm{P}$ application, and increased by the $\mathrm{P}$ rates (Figure 4). Genotypes and $\mathrm{P}$ rates had significant influence $(\mathrm{P}=0.001)$ on $\mathrm{P}$ uptake. $\mathrm{P}$ uptake raised as rates of $\mathrm{P}$ increased with addition of $\mathrm{P}$ rates in all genotypes (Figure 4).

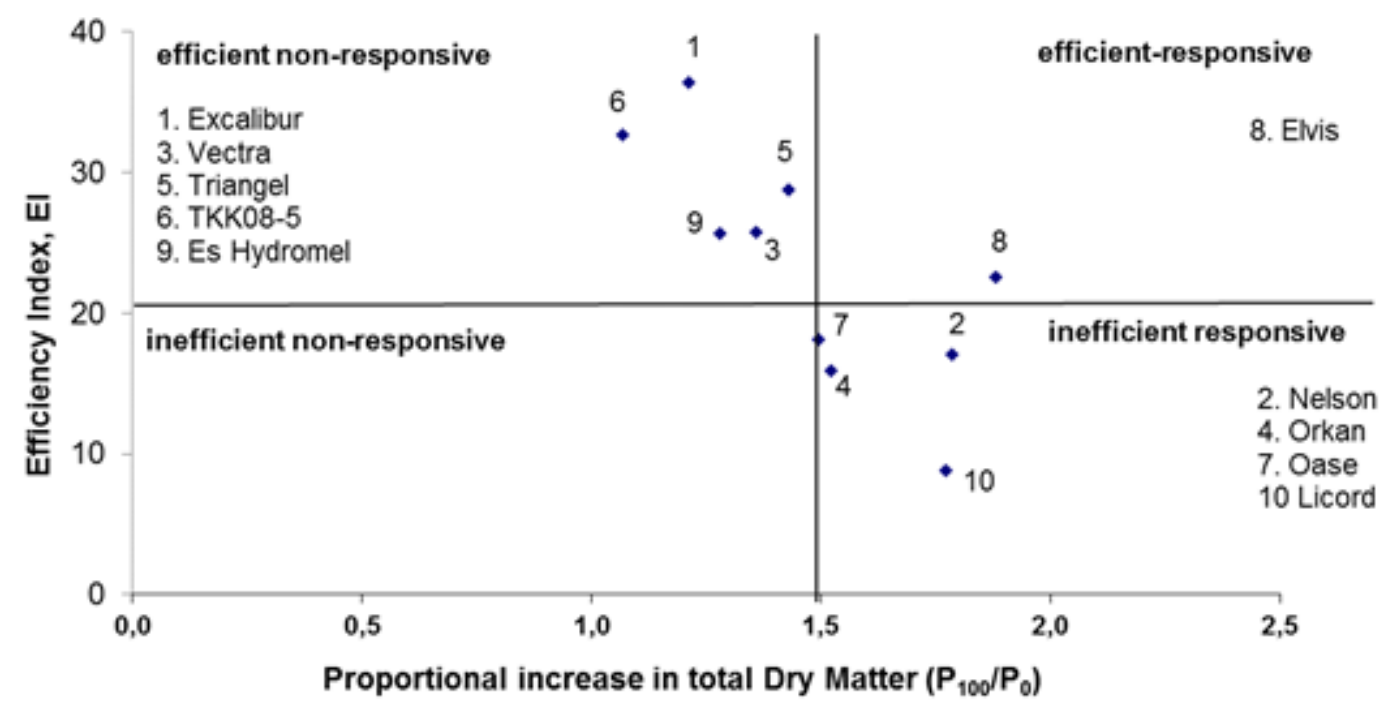

Figure 1 Classification of ten canola genotypes for the efficiency index (EI).

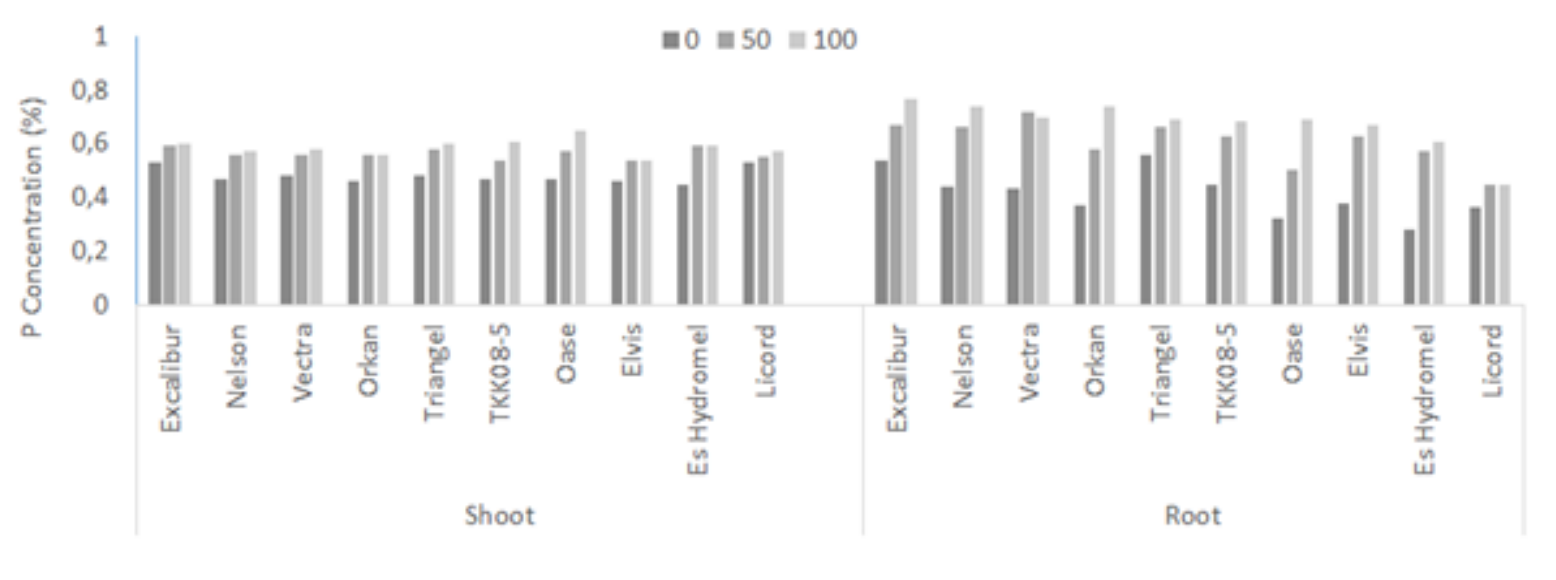

Figure 2 Shoot and root $\mathrm{P}$ concentration of the ten canola genotypes 


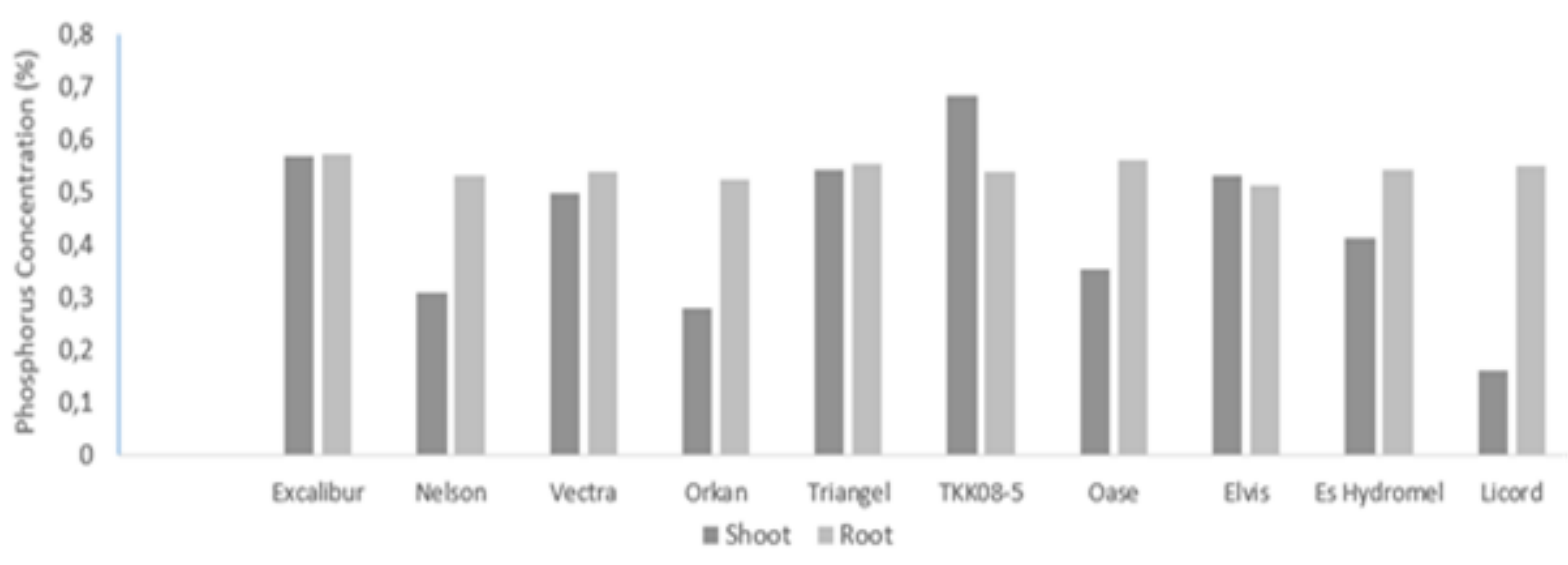

Figure 3 Means of shoot and root $\mathrm{P}$ concentration of the ten canola genotypes

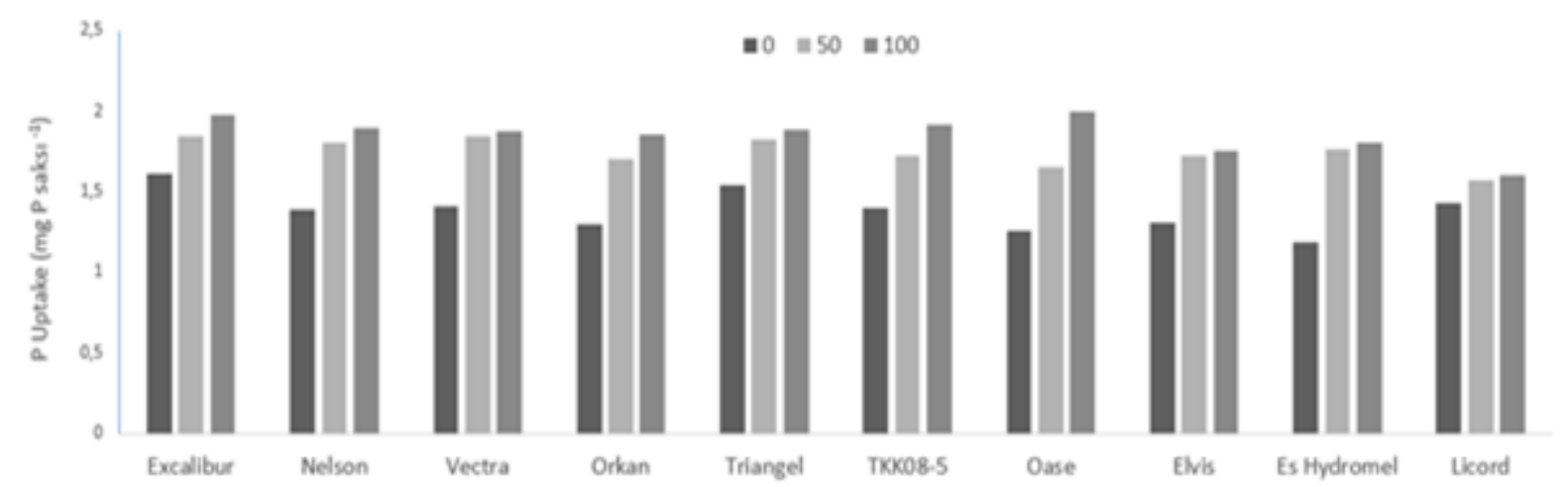

Figure 4 Overall $\mathrm{P}$ uptake of the canola genotypes with and without $\mathrm{P}$ fertilization.

\section{Discussion}

Phosphorus is an essential nutrient for canola production. Low available soil $\mathrm{P}$ and reduced plant PUE are some of the major constraints limiting canola yield. Ensuring a well-balanced supply of $\mathrm{P}$ to the crop may result in higher grain yield. Soil type, genotypic variability and phosphorus rates are the factors affecting canola yield. The results show that the adaptation of canola genotypes to low levels of soil P is closely related to genotypic differences. Genotypic differences were observed in dry weight among plant samples at each $\mathrm{P}$ rate (Table 3), especially at low level $\mathrm{P}$ conditions in soil. Root and shoot dry weight of the genotypes responded significantly to $\mathrm{P}$ application. Shoot and root dry matter were measured to determine development of canola as influenced by genotypes and $\mathrm{P}$ application levels. Our study indicated that greater shoot and root dry matter growth were attributed to the supply of $\mathrm{P}$ fertilizer, and clearly demonstrated the importance of P supply through the roots for canola growth in soils. It can be seen that with increasing P rate, shoot and root dry matter increased for all of the genotypes in the experiment. These results are in agreement with previous studies (Grant and Bailey 1993; Bhadoria et al 2002; Gill et al 2005). Ibrikci et al (2009) also reported that the application of P fertilizer increased root development and plant dry weight. Ozturk et al (2005) suggested that the shoot dry matter production and total amount of $\mathrm{P}$ per shoot at low $\mathrm{P}$ application are the most credible factors in evaluating plants for P efficiency at the early growth stage. All over, dry weight data demonstrated that genotypic variability and available $\mathrm{P}$ of soil were important factors affecting plant $\mathrm{P}$ response. Phosphorus deficiency in canola restricts both shoot and root growth. Fageria and Baligar (1997) stated significant differences in maize and Korkmaz et al (2009) reported significant differences in wheat genotypes for root dry matter and uptake and $\mathrm{P}$ use efficiency when grown at "low" and "high" application levels of $P$.

The efficiency index (EI) of the genotypes was defined as biomass production per unit of phosphorus in the plant tissue. Results of this study indicated that there were significant differences in EI among the genotypes in low $\mathrm{P}$ conditions. These great diversity may stem from plant-P need and differences for $\mathrm{P}$ acquisition and use. The results of this study suggest that phosphorus efficiency index (EI) is a reliable parameter for the identification of genotypes adapted to low or high $\mathrm{P}$ availability, but in order to be used as criteria for plant efficiency in P uptake and P utilization they need to be correlated to other P efficiency characteristics such soil factors as clay, $\mathrm{pH}$ and root parameters as root length and root surface area.

This result also showed that EI was a more characteristic parameter under $\mathrm{P}$ stressed conditions than 
that of $\mathrm{P}$ supplied conditions to characterize $\mathrm{P}$ use efficiency. Genotypic differences have been shown to be correlated with $\mathrm{P}$ use efficiency of plants in soils Many authors have reported possible mechanisms for genetic variations in plant nutrients (Fageria and Baligar 1993; Manske et al 2000; Korkmaz et al 2009). Plants are known to comply with several mechanisms to raise their $\mathrm{P}$ acquisition/ use efficiency, such as nutrient uptake from the rooting environment, nutrient movement across roots and delivery to the xylem and distribution within plant shoots, and nutrient-utilization metabolisms and growth (Ahmed et al 2001). The phosphorus uptake and use efficiency of the genotypes are influenced by both soil type and genetic factors. One of the most significant factors is the genotypic differences among plants. Thus, determination of $\mathrm{P}$ efficient genotypes has great importance in efficiency of $\mathrm{P}$ fertilization to gather the high yield with decreased $P$ fertilizer inputs, and we offer that $P$ use efficiency sould be involved in genetic improvement programs through breeding.

Compared to the control, all $\mathrm{P}$ treatments significantly raised $\mathrm{P}$ concentration of shoot and root in all genotypes (Figure 2). It shows that shoot and root phosphorus concentration vary considerably among $\mathrm{P}$ applications. Increasing $\mathrm{P}$ application rate increased linearly the plant phosphorus concentrations. It was found that phosphorus concentration in the root is remarkably higher than in the shoot at the inefficient-responsive genotypes: Nelson, Orkan, Oase, Licord, which produced under the average dry weight, but responded well to $\mathrm{P}$ treatments (Figure 3).

Increasing in $\mathrm{P}$ efficiency caused enhance in $\mathrm{P}$ uptake. This result indicates that not only enhanced $\mathrm{P}$ uptake but also enhanced internal utilization of $\mathrm{P}$ plays an important role in emphasis of high $\mathrm{P}$ efficiency. These results were in accordance with Baligar's (1997) in which significant differences reported among maize genotypes for P uptake. Analysis of variance showed that $\mathrm{P}$ uptake was significantly affected by $\mathrm{P}$ rates. In general scope, phosphorus uptake of the genotypes were linearly raised by P treatments (Alves et al 2001; Korkmaz et al 2009). In order to produce higher dry weight under low $\mathrm{P}$ conditions, canola genotypes can take up mainly more $\mathrm{P}$ from soil if the plant is $\mathrm{P}$ efficient. $\mathrm{P}$ efficient plants may not need have high $\mathrm{P}$ uptake, but these can also utilize internal $\mathrm{P}$ effectively to produce more dry weight. Phosphorus uptake and this uptake depends on plant characteristics such as $\mathrm{P}$ acquisition, translocation including transport, partitioning and remobilization and internal utilization of $\mathrm{P}$ in plant. So that, $\mathrm{P}$ efficient genotypes may have a high adaptation capacity to low $\mathrm{P}$ condition in soils.

In conclusion, genotypic manipulation of plant may be more effectives than $\mathrm{P}$ fertilizer application for uptake $\mathrm{P}$ by plants. Our study showed that tolerance to $\mathrm{P}$ deficiency was a complex trait in which many plant characteristics were involved and $\mathrm{P}$ efficient genotypes have a potential to improve canola yields on soils with low $\mathrm{P}$ availability

\section{References}

Alves VMC, Parentoni SN, Vasconcellos CA, Bahia Filho AFC, Pitta GVE, Schaffert RE. 2001. Mechanisms of phosphorus efficiency in maize. Plant Nutrition-Food Security and Sustainability of Agro-ecosystems. 566-567.

Baligar VC, Fageria NK, 1997. Nutrient use efficiency in acid soils: Nutrient management and plant use efficiency. Pp 75-95. In: A.C. Moniz, A.M.C. Furlani, R.E. Schaffert, N.K. Fageria, C.A. Ruselom, and H. Cantarella (eds.), Plant Soil Interactions at low pH: Sustainable Agriculture and Forestry Production. Brazilian Soil Science Society, Compinas, Brazil.

Bertrand RE, Holloway R, Armstrong D, Mclaughlin MJ. 2003. Chemical characteristics of phosphorus in alkaline soils from southern Australia. Australian Journal of Soil Research. 41: 6176.

Bhadoria PS, Steingrobe B, Claassen N, Liebersbach H. 2002. Phosphorus efficiency of wheat and sugar beet seedlings grown in soils with mainly calcium, or iron and aluminium phosphate. Plant and Soil. 246: 41-52.

Blair G. 1993. Nutrient Efficiency-what do we really mean? In: Genetic Aspects of Plant Mineral Nutrition, eds., P. J. Randall, E. Delhaize, R. A. Richards, and R. Munns, p. 204-213. Dordrecht, the Netherlands: Kluwer.

Bolland MDA 1997. Comparative phosphorus requirement of canola and wheat. Journal of Plant Nutrition. 20 (7-8): 813-829.

Brennan RF, Mason MG, Walton GH. (2000). Effect of nitrogen fertilizer on the concentrations of oil and protein in canola (brassica napus) seed. Journal of Plant Nutrition. 23 (3): 339348.

Erkovan HI, Güllap MK, Daşçi M and Koç A. 2010. Effects of phosphorus fertilizer and phosphorus solubilizing bacteria application on clover dominant meadow: I. Hay yield and botanical composition. Turkish Journal of Field Crops, 15(1): $12-17$

Fageria NK, Baligar VC. 1993. Screening Crop Genotypes for Mineral Stresses. In Adaptation of Plants to Soil Stresses; University of Nebraska:Lincoln, NE, INTSORMIL Publ. No. 94 (2): $142-162$

Fageria NK, Baligar VC. 1999. Phosphorus efficiency in Wheat Genotypes. Journal of Plant Nutrition. 22(2): 331-340.

Fohse D, Claassen N, Jungk A. 1991. Phosphorus efficiency of plants. II. Significance of root radius, root hairs and cation anion balance for phosphorus influx in seven plant species. Plant Soil. 132: 262-271.

Gerloff S. 1977. Plant efficiencies in the use of N, P and K. In: Plant Adaptation to Mineral Stress in Problem Soils, ed., M. J.Wright, pp. 161-174. Ithaca, NY: Cornell University Press.

Gill AA, Sadana US, Samal D. 2005. Phosphorus influx and rootshoot relations as indicators of phosphorus efficiency of different crops. Communications in Soil Science and Plant Analysis. 36: 2315-2327.

Grant CA, Bailey LD. 1993. Fertility management in canola production. Canadian Journal of Plant Science. 73: 651-670.

Ibrikci H, Ulger AC, Korkmaz K, Oktem A, Buyuk G, Ryan J, Amar B, Konuskan O, Karnez E, Ozgenturk G, Cakir B, Oguz H. 2009. Genotypic Responses of Corn to Phosphorus Fertilizer Rates in Calcareous Soils, Communications in Soil Science and Plant Analysis. 40: 1418-1435.

Korkmaz K, Ibrikci H, Karnez E, Buyuk G, Ryan J, Ulger AC and Oguz H. 2009. Phosphorus Use Efficiency of Wheat Genotypes Grown in Calcareous Soils. Journal of Plant Nutrition. 32: 2094-2106.

Manske GGB, Ortiz-Monasterio JI, Van Ginkel M, Gonzalez RM, Rajaram S, Molina E and Vlek PLG. 2000. Traits associated with improved P-uptake efficiency in CIMMYT's semi-dwarf spring bread wheat grown on an acid Andisol in Mexico. Plant Soil. 221: 189-204

Kirkby EA, Mengel K. 1987. Principles of Plant Nutrition 4. ed. Int. Potash. Inst. Bern, Switzerland. 
Murphy J, Riley JP. 1962. A modified single solution method for the determination of phosphate in natural waters. Anal. Chim. Acta. 27: 31-36.

Ozturk L, Eker S, Torun B, Cakmak I. 2005. Variation in phosphorus efficiency among 73 bread and durum wheat genotypes grown in a phosphorus-deficient calcareous soil. Plant and Soil. 269: 69-80.

Rengel Z. 1999. Physiological mechanisms underlying differential nutrient efficiency of crop genotypes. In: Z Rengel (ed) Mineral nutrition of crops: fundamental mechanisms and implications. Food Products Press, New York, pp 227-265.

Saltali, K, Kılıç, K, Koçyiğit, R. 2007. Changes in Sequentially Extracted Phosphorus Fractions in Adjacent Arable and Grassland Ecosystems. Arid Land Research and Management, 21:81-89.
Sharpley AN, Chapra SC, Wedepohl R, Sims JT, Daniel TC, and Reddy KR. 1994. Managing agricultural phosphorus for protection of surface waters: Issues and options. J. Environ. Qual. 23: 437-451.

Siddiqi MY, Glass ADM. 1981. Utilization Index: A modified approach to estimation and comparison of nutrient utilization efficiency in plants. Journal of Plant Nutrition. 4: 289-302.

Terence R, Lynch JP. 2001. Root hairs confer a competitive advantage under low phosphorus availability. Plant and Soil. 236: 243-250.

Watt M, Evans JR. 1999. Proteoid Roots. Physiology and Development. Plant Physiology. 121: 317-323.

Wissuwa M. 2003. How do plants achieve tolerance to phosphorus deficiency? Small causes with big effects. Plant Physiology. 133: 1947-1958.

Vance CP, Uhde-Stone C, Allan DL. (2003). Phosphorus acquisition and use: Critical adaptations by plants for securing a nonrenewable resource. New Phytologist. 157:423-447 